\title{
PENGGUNAAN VIDEO DIKOMBINASIKAN DENGAN MODEL PEMBELAJARAN INVESTIGASI KELOMPOK UNTUK MENINGKATKAN HASIL BELAJAR SISWA MAN 2 PONTIANAK
}

\author{
Rina $^{1}$, Rika Anggela ${ }^{2}$, Ivan Veriansyah ${ }^{3}$ \\ 1,2,3 Program Studi Pendidikan Geografi \\ Fakultas Ilmu Pendidikan dan Pengetahuan Sosial IKIP PGRI Pontianak \\ Jalan Ampera Nomor 88 Pontianak - 78116, Telepon (0561) 748219 Fax. (0561) 589855 \\ ${ }^{1}$ Alamat e-mail: rinac4hy4n1@gmail.com
}

\begin{abstract}
Abstrak
Tujuan penelitian untuk mendapatkan informasi secara jelas, objektif dan sistematis tentang penggunaan media video dalam meningkatkan hasil belajar pada siswa kelas XI IPS MAN2 Pontianak T.A. 2017/2018. Penelitian ini merupakan penelitian tindakan yang dilakukan secara partisipatif. Pendekatan yang digunakan adalah pendekatan kualitatif. Penelitian ini dilakukan di MAN 2 Pontianak. Pelaksanaan tindakan dilakukan dalam 3 siklus. Subjek penelitian adalah siswa Kelas XI IPS 4 berjumlah 31 orang. Instrumen pengumpulan data berupa soal tes, panduan observasi dan dokumentasi. Teknis analisis datadilakukan secara kualitatif untuk menggambarkan aktifitas siswa yang diakumulasikan melalui hasil observasi di setiap siklusdan rata-rata untukhasilbelajar. Hasil penelitian diketahui pengunaan media pembelajaran sudah baik, terlihat dari pelaksanaan pembelajaran siklus I,siklus II dan siklus III. Afektif siklus I yaitu 60\%, siklus II yaitu 76\%,siklus III yaitu $88 \%$. Aspek psikomotorik hasil siklus I yaitu56\%, siklus II yaitu $76 \%$ siklus III yaitu $92 \%$ dan hasil belajar siklus I yaitu 19\%, siklus II yaitu 67\%, siklus III yaitu $97 \%$.
\end{abstract}

Kata Kunci: Media Video, Model Investigasi Kelompok, Hasil Belajar

\begin{abstract}
The purpose of research to obtain information clearly, objectively and systematically about the use of video media in improving learning outcomes in students class XI IPS MAN2 Pontianak T.A. 2017/2018. This research is a participatory action research. The approach used is qualitative approach. This research was conducted at MAN 2 Pontianak. Implementation of the action is done in 3 cycles. The subjects of the study were students of Class XI IPS 4 totaling 31 people. The instruments of data collection are test questions, observation guides and documentation. Technical data analysis is done qualitatively to illustrate the activities of students who are accumulated through the observation results in each cycle and the average for learning outcomes. The result of the research is known the use of learning media is good, seen from the implementation of learning cycle I, cycle II and cycle III. The first cycle affectivity is 60\%, the second cycle is $76 \%$, the third cycle is $88 \%$. Psychomotor aspects of cycle I are $56 \%$, cycle II is $76 \%$ cycle III that is $92 \%$ and the result of learning cycle I is 19\%, cycle II is $67 \%$, cycle III that is $97 \%$.
\end{abstract}

Keywords: Video, Investigation Group Model, Learning Outcomes

\section{PENDAHULUAN}


Peranan dan kompetensi guru dalam proses belajar mengajar meliputi banyak hal, guru sebagai pengajar, pengelola kelas, pembimbing, pengatur lingkungan, partisipan, ekspeditor, perencana, supervisor, motivator, fasilitator, dan konselor. Guru yang kompeten akan mampu menciptakan lingkungan belajar yang efektif dan akan lebih mampu mengelola kelasnya sehingga hasil belajar siswa berada tingkat optimal. Media pembelajaran menurut (Arsyad, 2013) memiliki fungsi utama sebagai alat bantu mengajar yang ikut mempengaruhi iklim, kondisi, dan lingkungan belajar yang ditata dan diciptakan oleh guru. Dalam pembelajaran, media memiliki fungsi sebagai pembawa informasi dari sumber (guru) menuju penerimaan (siswa). Media berfungsi mengarahkan siswa untuk memperoleh berbagai pengalaman belajar (learning experience). Media yang dipergunakan dalam pembelajaran memungkinkan terjadinya interaksi langsung antara siswa dengan materi pelajaran, karena melalui media siswa akan memperoleh pengalaman lebihluas dan lebih lengkap. Keluasan materi yang didapat oleh siswa ini akan menimbulkan minat belajar yang baru. Konsep yang dijelaskan oleh media dapat disajikan dengan rekreatif dan menarik (Anitah, 2012). Dapat disimpukan bahwa media adalah sarana untuk menuju suatu yang didalamnya terkandung informasi yang dapat dikomunikasikan kepada orang lain. Informasi itu antara lain bisa didapatkan dari buku, internet, software (perangkat lunak) contohnya program SIG, hardware (perangkat keras) komputer dan LCD proyektor.

Pemilihan media yang tidak tepat guna akan menjadi penghalang kelancaran jalannya proses belajar mengajar. Oleh karena itu, media dan pendekatan yang dipilih oleh seorang guru, akan mendapat hasil yang optimal jika mampu mencapai tujuan yang ditetapkan yaitu meningkatnya hasil belajar siswa.

Media diperlukan dalam pembelajaran karena mempunyai kemampuan/ potensi yang dapat dimanfaatkan. Juga media mempunyai kelebihan yang dapat mengatasi kekurangan- kekurangan penyampaian pesan guru. Media yang efektif adalah media yang mampu mengkomunikasikan sesuatu yang ingin disampaikan oleh pemberi pesan kepada penerima pesan. Jadi proses penerimaan dipengaruhi oleh media. Media pembelajaran juga berpengaruh terhadap pemahaman siswa 
pada suatu konsep materi. Salah satu yang dianggap menarik perhatian siswa adalah media video Dalam hal ini yang akan duginakan adalah media Video.

Penggunaan media perlu dikombinasikan dengan media atau model pembelajaran lain agar mampu meningkatkan hasil belajar siswa dalam belajar Geografi sehingga siswa lebih tertarik belajar Geografi. Model pembelajaran Investigasi Kelompok dapat dikombinasikan dengan media Video, agar siswa mampu menganalisi video secara kelompok.

Bedasarkan kerucut pengalaman belajar secara kongkret. Pengalaman langsung akan memberikan kesan paling baik dari isi informasi, karena melibatkan indera penglihatan, pendengaran, perasaan, penciuman dan perabaan. Semakin menuju ke puncak kerucut. Pemilihan media yang tidak tepat guna akan menjadi penghalang kelancaran jalannya proses belajar mengajar. Oleh karena itu, media dan pendekatan yang dipilih oleh seorang guru, akan mendapat hasil yang optimal jika mampu mencapai tujuan yang ditetapkanya itu meningkatnya hasil belajar siswa.

Media diperlukan dalam pembelajaran karena mempunyai kemampuan/ potensi yang dapat dimanfaatkan.Media mempunyai kelebihan dapat mengatasi kekurangan- kekurangan penyampaian pesan guru. Media yang efektif adalah media yang mampu mengkomunikasikan sesuatu yang ingin disampaikan oleh pemberi pesan kepada penerima pesan. Jadi proses penerimaan dipengaruhi oleh media. Media pembelajaran juga berpengaruh terhadap pemahaman siswa pada suatu konsep materi. Salah satu yang dianggap menarik perhatian siswa adalah media video. Dalam hal ini yang akan digunakan adalah media Video.

(Riyana, 2007) media video pembelajaran adalah media yang menyajikan video dan visual yang berisi pesan pesan pembelajaran baik yang berisi konsep, prinsip, prosedur, teori aplikasi, pengetahuan untuk membantu pemahaman terhadap suatu materi pembelajaran .

Video sebagai media audio visual menampilkan gerak, semakin lama semakin populer dalam masyarakat pada saat ini. Pesan yang disajikan bersifat fakta naupun fiktif, bias bersifat informatif, edukatif maupun instruksional (Sadiman, 2012). Video tersedia hampir untuk semua jenis topik dan untuk 
seluruh pembelajraan diseluruh ranah pembelajaran kognitif, afektif, kemampuan motorik, interpesonal. Mereka bisa membawa pembelajaran hampir kemana saja memperluas minat siswa melampaui dinding ruang kelas.

Video merupakan bahan pembelajaran tampak dengar (audio visual) yang dapat digunakan untuk menyampaikan pesan pesan atau materi pembelajaran. Dikatajan tampak dengar karena unsur dengar dan unsur visual dapat disajikan serentak. Video yaitu bahan pembelajaran yang dikemas melalui pita video dan dapat dilihat melalui video yang dihubungkan melalui video yang dihubungkan ke monitor televisi (Miskowati, 2012)

Video tersedia hampir untuk semua jenis topik dan untuk seluruh pembelajraan diseluruh rana pembelajaran kognitif, afektif, kemampuan motorik, interpesonal. Mereka bisa membawa pembelajaran hampir kemana saja memperluas minat siswa melampaui dinding ruang kelas.Penggunaan media perlu dikombinasikan dengan media atau model pembelajaran lain agar mampu meningkatkan hasil belajar siswa dalam belajar Geografi sehingga siswa lebih tertarik belajar Geografi. Model pembelajaran Investigasi Kelompok dapat dikombinasikan dengan media video, agar siswa mampu menganalisi video secara kelompok (Lingin, 2012).

(Arifin, 2014) Hasil belajar adalah segala sesuatu yang diperoleh siswa dalam pengalaman-pengalaman atau latihan-latihan yang diikutinya selama pembelajaran yang berupa keterampilan kognitif, afektif, dan psikomotor. Bloom dalam (Gunawan, 2016) membedakan hasil belajar dalam tiga aspek: (a) Aspek kognitif, (b) Aspek afektif, (c) Aspek psikomotorik. Hasil belajar berupa angka yang dapat memberikan informasi kepada guru tentang kemajuan siswa dalam upaya pencapaian tujuan belajarnya melalui kegiatan belajarnya.

Meningkatkan hasil belajar guru dituntut untuk benar-benar mengetahui karakteristik tiap anak didik. Sehingga media dan pendekatan yang diterapkan dalam proses belajar dan pembelajaran pun benar- benar searah dengan perkembangan diri siswa yang menjadi subjek sekaligus objek pendidikan itu sendiri, serta mampu meningkatkan hasil belajar siswa (Dwi Rahmawati, 2012). Untuk dapat meningkatkan hasil belajar siswa, yang menjadi ujung tombak 
pendidikan adalah guru. Sebab guru secara langsung berupaya mempengaruhi, membina, dan mengembangkan kemampuan siswa agar menjadi manusia yang cerdas, terampil, dan bermoral tinggi. Guru sebagai pengajar paling tidak harus menguasai bahan yang diajarkan dan terampil dalam menyampaikan materi yang diajarkan. Proses pembelajaran yang baik didukung oleh media pembelajaran yang tepat, Ketertarikan dan peningkatan hasil belajar siswa dapat diupayakan dengan mengguanakan media pembelajaran yang kreatif dan menarik (Sulasti, 2013).

Untuk itu perlu adanya suatu metode pembelajaran yang diharapkan mampu untuk meningkatkan hasil belajar siswa kelas XI IPS 4. Media video dipilih sebagai alternative untuk memecahkan masalah tersebut dan di kombinasikan dengan pembelajaran Investigasi kelompok. Dalam metode ini, para siswa dibebaskan membentuk kelompoknya sendiri yang terdiri dari duasampai enam orang anggota. Kelompok ini kemudian memilih topik-topik dari unit yang telah dipelajari oleh seluruh kelas, membagi topik-topik ini menjadi tugas-tugas pribadi, dan melakukan kegiatan yang diperlukan untuk mempersiapkan laporan kelompok. Tiap kelompok lalu mempresentasikan atau menampilkan penemuan mereka di hadapan seluruh kelas. (Haryoko, 2009) Media video digunakan dalam pembelajaran. Karena media pembelajaran video menyajikan berbagai gambar yang menarik serta cara belajar yang mengharuskan siswa untuk dapat berpartisipasi dan lebih aktif.

Media Video didukung dengan memakai pendekatan kooperatif tipe Investigasi Kelompok yang membantu siswa untuk dapat bekerja dan belajar secara kelompok serta mampu bekerja sama. Kombinasi media video dengan investigasi kelompok mengajarkan siswa untuk menganalisis gambar secara kelompok agar mampu memahami materi sehingga hasil belajar meningkat.

\section{METODE}

Penelitianini merupakan penelitian tindakan. Pendekatan yang digunakan adalah pendekatan kualitatif. Bentuk penelitian ini adalah penelitian tindakan kelas yang dilakukan secara partisipatif. Peneliti tidak melakukan penelitian 
sendiri. Penelitian Tindakan Kelas ini dilakukan di MAN2 Pontianak. Penelitian ini dilaksanakan pada Bulan Mei 2017. Pelaksanaan tindakan dilakukan dalam tiga siklus dan pada setiap siklus terdapat satu kali pertemuan. Setiap pertemuan memiliki durasi 2 x 45 menit.

Subjek penelitian ini adalah mahasiswaKelas XI IPS 4 MAN 2 Pontianak berjumlah 31 orang. Alasan pemilihan kelas XI IPS 4, kelas tersebut memiliki aktifitas di kelas sangat rendah yang berdampak pada hasil belajarnya. Dalam penelitian ini guruakan menggunakan media video yang di kombinasikan dengan model pembelajaran investigasi kelompok.

Teknik pengumpulan data yang digunakan adalah teknik pengukuran, teknik observasi langsung dan studi dokumenter. Teknik pengukuran instrument yang di gunakan adalah soal tes untuk mengukur hasil belajarnya. Teknik observasi langsung menggunakan instrumen berupa lembar observasi yang ditujukan untuk siswa selaku subjek penelitian. Instrumen lain yang digunakan adalah berupa dokumentasi untuk memperoleh data dengan mengumpulkan berkas-berkas atau arsip yang dianggap penting dalam penelitian.Teknis analisis data yang dilakukan secara kualitatif untuk menggambarkan aktifitas siswa pada saat proses belajarberlangsung diakumulasikan melalui hasil observasi di setiap siklus dan untuk hasil belajar mengunakan rumus rata rata.

\section{HASIL DAN PEMBAHASAN}

Proses pembelajaran mata pelajaran Geografi selama siklus I sampai siklus III berlangsung hasilnya peningkatan terhadap hasil belajar siswa selama mengikuti pembelajaran. Selain itu selama proses pembelajaran dengan menggunakan media video dikombinasikan dengan model pembelajaran investigasi kelompok siswa sudah menunjukkan perubahan kearah yang lebih baik. Hal ini dapat dilihat dari perolehan hasil belajar siswa yang mencapai ketuntasan baik secara klasikal maupun individual pada mata palajaran Geografi khususnya sub pokok bahasan "Biosfer".

Pada rencana pembelajaran siklus I tiga tujuan yang ingin dicapai setelah proses pembelajara selesai dilaksanakan, yaitu siswa mampu menjelaskan 
pengertian biosfer, yang kedua siswa mampu menjelaskan tingkatan jenjang kehidupan dan tujuan yang terakhir yaitu siswa mampu mengemukakan faktorfaktor yang mempengaruhi persebaran flora dan fauna. Kegiatan pembelajaran dimulai dengan mempersiapkan media video yang digunakan dalam pembelajaran. Menjelaskan langkah-langkah pembelajaran dan membagi siswa dalam kelompok.

Test formatif diberikan pada akhir pemebelajaran siklus I menggunakan media videodikombinasikan investigasi kelompok. Test formatif bertujuan mengetahui hasil belajar siswa pada siklus I, terdiri dari 25 pertanyaan soal pilihan ganda. Selain itu guru juga mengadakan pengamatan untuk menilai aspek afektif dan psikomotorik siswa menggunakan lembar observasi yang dilakukan oleh guru.

Palaksanaan pembelajaran menggunakan media videosebagai pengantar proses pembelajaran diawali menggunakan metode ceramah untuk memudahkan siswa memahami tujuan pembelajaran. Langkah selanjutnya memberikan intruksi siswa untuk mengikuti langkah-langkah pemebelajaran dengan menggunakan media videodengan model pembelajaran investigasi kelompok. Langkah terakhir dalam pemebelajaran ini adalah siswa mempersentasikan hasil diskusi kelompoknya di depan kelas.

Pada hasil refleksi siklus I masih ditemui banyak kekurangan, diantaranya hasil belajar siswa belum mencapai indikator ketuntasan yang diharapkan, perhatian guru terhadap siswa juga masih perlu untuk ditingkatkan. Hal ini menunjukkan siswa tersebut masih kurang memahami materi, oleh karena itu siswa belum siap menghadapi tes formatif yang dilakukan secara tiba-tiba, ini menunjukkan bahwa siswa tidak selalu belajar mandiri di rumah.

Mengacu pada siklus I, pelaksanaan pembelajaran siklus II dapat dilaksanakan dengan baik, siswa sudah mengetahui tentang proses serta tugas dan tanggung jawab dalam kegiatan pembelajaran walaupun siswa sudah berani untuk menyampaikan ide ke temannya serta memberikan tanggapan jika ada yang kurang sesuai dengan pendapat teman yang lain, sehingga proses pembelajaran sesuai denga rencana, walaupun tanggapan yang diberikan masih kurang 
sistematis. Hasil dari pembelajaran siklus II, rata-rata evaluasi kelas 80 dengan ketuntasan belajarnya $68 \%$ serta keaktifan siswa dalam pembelajaran sudah baik.

Hasil refleksi siklus II menunjukkan sudah terdapat peningkatan aktivitas belajar siswa. Siswa sudah mengenal dan menyukai media video dikombinasikan dengan model pembelajaran investigasi kelompok, guru juga sudah melakukan refleksi diri sehingga pada proses pembelajaran siklus II perhatian guru terhadap siswa juga semaikin baik. Hasil pengamatan dan penilaian guru masih ada siswa yang belum aktif dan dapat bekerjasama dengan baik saat diskusi, ada beberapa siswa juga yang belum mengungkapkan jawabannya secara jelas, tepat dan sistematis.

Hasil refleksi siklus III sudah mengalami peningkatan dari proses pembelajaran sampai dengan tahapan evaluasi. Pelaksanaannya sudah berjalan dengan baik dengan bertambahnya aktivitas siswa dalam menyajikan atau menjelaskan materi pelajaran di depan kelas, keaktifan siswa dalam mengajukan pertanyaan dan menanggapinya juga sudah baik. Hal ini tentunya juga tidak lepas dari perhatian guru pada siswa yang semakin meningkat.Peningkatan hasil dari siklus I, siklus II dan siklus III dapat dilihat dalam Tabel 1.

Tabel 1. Rekaptulasi Hasil Belajar Siswa

\begin{tabular}{|c|l|l|l|}
\hline Rata $-\mathrm{r}$ ata & Siklus & Siklus II & Siklus III \\
\hline Nilai Akhir Siklus & 65 & 80 & 86 \\
\hline $\begin{array}{l}\text { Jumlah siswa yg nilainya } \\
\geq 75\end{array}$ & 6 & 21 & 30 \\
\hline $\begin{array}{l}\text { Ketuntasan klasikal tes } \\
\text { akhir siklus (\%) }\end{array}$ & 19 & 67 & 97 \\
\hline
\end{tabular}

Hasil belajar siswa pada test akhir siklus III sudah sangat baik. Rata-rata nilai siswa yaitu 86 dengan persentase ketuntasan 97\%. Hal ini menunjukkan bahwa indikator penelitian tercapai, $\geq 80 \%$ siswa nilaianya $\geq 75$. Hasil belajar dapat di Visualisasikan pada diagram Gambar 1 berikut ini : 


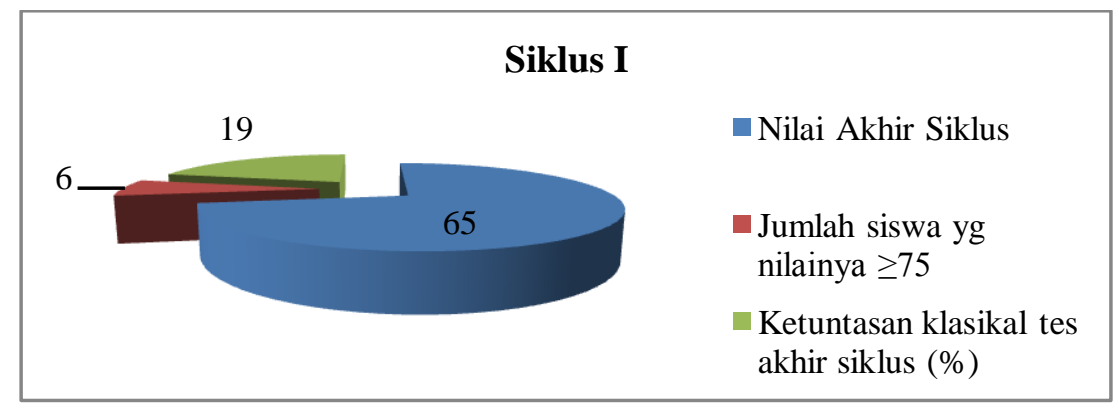

Gambar 1. Hasil Belajar Tiap Siklus

Berdasarkan tabel siklus I rata-rata nilai siswa adalah $65 \%$ persentaseketuntasan klasiskan 19\%. Pada siklus II rata-rata nilai siswa meningkat mejadi 80 dengan peningkatan pula pada ketuntasan klasikal yaitu sebesar $48 \%$, sehingga ketuntasan menjadi $67 \%$. Sedangkan pada siklus III nilai rata-rata siswa kembali meningkat menjadi 86 dengan ketuntasan klasikal sebesar 97\%, atau mengalami peningkatan sebesar $30 \%$.

Hasil pengamatan dan penilaian terhadap aktivitas belajar siswa yaitu aspek afektif dan aspek psikomotorik pada siklus I, siklus II dan siklus III dapat dilihat dalam tabel 2

Tabel 2. Rekaptulasi Aspek Afektif

\begin{tabular}{|c|l|c|c|c|}
\hline No. & \multicolumn{1}{|c|}{ Aspek yang diamati } & Siklus I & Siklus II & Siklus III \\
\hline 1 & $\begin{array}{l}\text { Kemauan untuk menerima } \\
\text { pelajaran }\end{array}$ & 3 & 4 & 4 \\
\hline 2 & $\begin{array}{l}\text { Kemauan untuk belajar } \\
\text { menggunakan media } \\
\text { videodikombinasikan } \\
\text { dengan } \\
\begin{array}{l}\text { pembelajaran investigasi } \\
\text { kelompok }\end{array}\end{array}$ & 4 & 4 \\
\hline $\begin{array}{l}\text { Menyukai } \text { belajar } \\
\text { menggunakan model } \\
\text { menggunakan } \\
\text { videodikombinasikan } \\
\text { dengan }\end{array}$ & 4 & 5 \\
\hline
\end{tabular}




\begin{tabular}{|l|l|c|c|}
\hline $\begin{array}{l}\text { pembelajaran investigasi } \\
\text { kelompok }\end{array}$ & 3 & 3 & 4 \\
\hline $\begin{array}{l}\text { Perhatian terhadap apa } \\
\text { yang dijelaskan }\end{array}$ & 3 & 4 & 5 \\
\hline $\begin{array}{l}\text { Bertanggung jawab } \\
\text { sebagai anggota tim }\end{array}$ & 3 & 3,8 & 4,4 \\
\hline Rata-rata & 60 & 76 & 88 \\
\hline$\%$
\end{tabular}

Aspek afektif pada siklus I skor rata-rata 3 dengan persentase $60 \%$. Pada siklus II mengalami peningkatan sebesar $16 \%$, sehingga siklus II meningkat menjadi $76 \%$ dengan skor rata-rata 3,8. Pada siklus III skor rata-rata sebesar 4,4 dengan peningkatan sebesar $12 \%$, sehingga siklus III meningkat menjadai $88 \%$. Rekapitu;lasi aspek afektif dapat dilihat pada Visualisasi Gambar 2 di bawah ini:

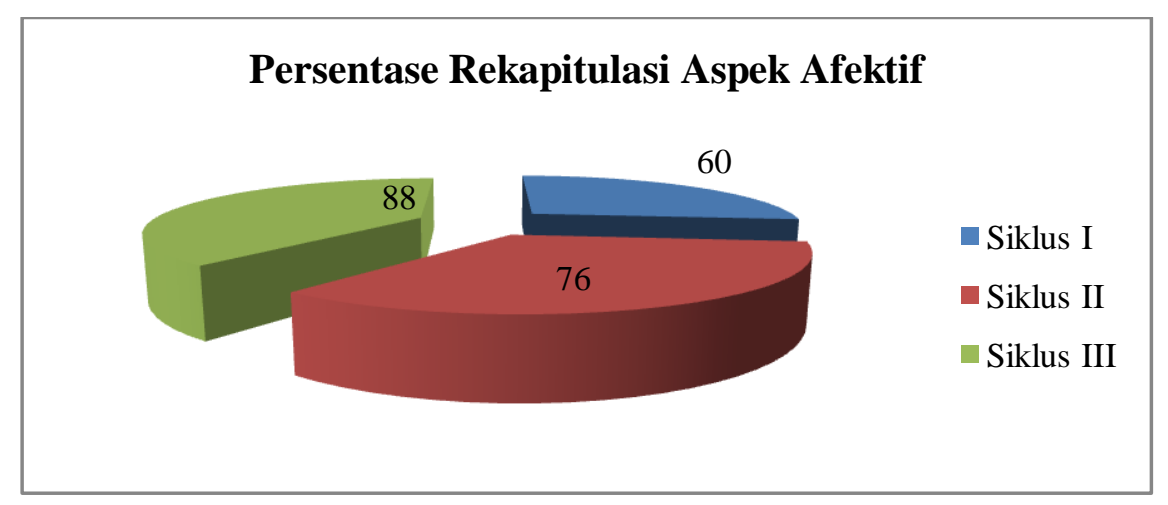

\section{Gambar 2: Rekapitulasi Aspek Afektif}

Sedangkan pengamatan pada aspek psikomotorik siswa hasilnya dapat dilihat pada Tabel 3 .

Tabel 3. Rekaptulasi Aspek Psikomotorik

\begin{tabular}{|c|l|l|l|l|}
\hline No. & Aspek yang diamati & Siklus I & $\begin{array}{l}\text { Siklus } \\
\text { II }\end{array}$ & $\begin{array}{l}\text { Siklus } \\
\text { III }\end{array}$ \\
\hline 1 & $\begin{array}{l}\text { Terampil dalam mengemukakan } \\
\text { pendapat }\end{array}$ & 3 & 4 & 5 \\
\hline 2 & Terampil dalam memecahan & 3 & 4 & 5 \\
\hline
\end{tabular}




\begin{tabular}{|c|l|l|c|c|}
\hline & masalah & & \\
\hline 3 & $\begin{array}{l}\text { Terampil dalam menggunakan } \\
\text { media video dikombinasikan } \\
\text { dengan model pembelajaran } \\
\text { investigasi kelompok }\end{array}$ & 2 & 3 & 4 \\
\hline 4 & Terampil dalam bekerja sama & 3 & 4 & 5 \\
\hline 5 & $\begin{array}{l}\text { Terampil merespon atau } \\
\text { menjawab pertanyaan }\end{array}$ & 3 & 4 & 5 \\
\hline Rata-rata & 2,8 & 3,8 & 4,6 \\
\hline
\end{tabular}

Berdasarkan tabel tersebut, didapatkan hasil pada siklus I rata-rata skor siswa adalah 2,8 dengan persentase 56\%. Pada siklus ke II meningkat menjadi $76 \%$ atau sebesar 20\% dengan rata-rata skor sebesar 3,8. Pada siklus III mengalami peningkatan kembali, rata-rata siswa yaitu sebesar 4,6 dan persentase meningkat sebesar $16 \%$ dari siklus II ke siklus III menjadi $92 \%$.

Visualisasi Rekapitulasi Aspek Psikomotorik dapat di lihat pada gambar 3 di bawah ini:

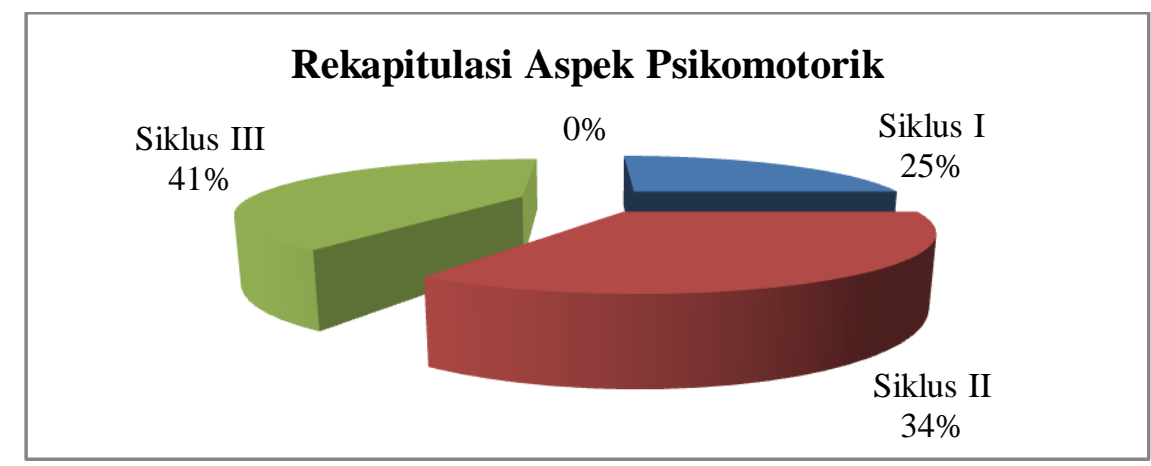

\section{Gambar 3. Rekapitulasi Aspek Psikomotorik}

Peningkatan aspek afektif dan aspek psikomotorik karena siswa yang semula belum pernah menggunakan media videodan model pembelajaran investigasi kelompok di awal pembelajaran masih mengalami kebingungan, dan belum berani mengungkapkan pendapatnya sendairi atau masih mau-malu. Tapi setelah berjalan sampai siklus II dan III aktivitas belajar siswa mulai mengalami 
peningkatan, karena siswa sudah mulai mengenal media da model pembelajaran yang digunakan. Siswapun mulai terlibat lebih aktif dan dapat mengerjakan tugas mereka dengan baik.

Hasil pembelajaran yang sudah dilaksanakan jelaskan bahwa dengan media videodikombinasikan dengan model pembelajaran investigasi kelompok, yang cara penyajiaannya dilaksanakan oleh siswa sendiri di depan kelas, sehingga menuntut siswa untuk lebih aktif, ternyata dapat meningkatkan hasil belajar belajar siswa.

Bedasarkan teori yang dikemukakan oleh Edgar Dale. Ia menyatakan bahwa hasil belajar seseorang diperoleh mulai dari pengalaman langsung (kongkret) berdasarkan kenyataan yang ada di lingkungan hidupnya, kemudian melalui benda-benda tiruan, dan selanjutnya sampai kepada lambang-lambang verbal (abstrak). Untuk kondisi seperti inilah kehadiran media pembelajaran menjadi sangat signifikan bagi terciptanya proses dan hasil pembelajaran yang optimal. Media diharapkan dapat merangsang keterlibatan berbagai alat indera atau dimaksimalkan bagi seluruh alat indera pembelajar. Di samping itu, Edgar Dale memberikan solusi untuk memecahkan persoalan berdasarkan tingkat keabstrakan pengalaman yang dihadapi peserta didik. Kenyataan ini didukung oleh landasan teori penggunaan media yang Bagan, diagram, grafik, dan sejenisnya. Dari uraian di atas dapat disimpulkan bahwa semakin konkret pengalaman siswa terhadap materi pembelajaran maka akan semakin besar ingatannya atau pemahamannya terhadap materi pelajaran tersebut.

Jean Piaget mengemukakan bahwa seseorang memiliki tingkatan berfikir sesuai dengan perkembangan usianya. Dalam pengenalan lingkungan itu, pebelajar melalui tiga tahapan belajar, yaitu tingkat kongkrit, tingkat skematis dan tingkat abstrak. Pada aspek kognitif, video dapat memanfaatkan untuk membelajarkan hal-hal yang terkait dengan pengetahuan dan intelektual siswa. Tujuan pembelajaran pada aspek kognitif adalah untuk melatih kemampuan intelektual siswa.

Mengacu pada teori di atas dan hasil tindakan kelas di atas, dari siklus I sampai siklus III siswa yang tuntas belajar sudah mencapai 97\% dalam 
pembelajaran juga menunjukkan peningkatan. Sehingga dapat dikatakan bahwa dalam penelitian tindakan kelas ada peningkatan hasil belajar siswa pada pokok bahasan Biosfer menggunakan media video dikombinasikan dengan model pembelajaran investigasi kelompok pada siswa kela XI IPS 4 MAN 2 Pontianak Tahun Pelajaran 2017/2018.

\section{SIMPULAN}

1. Langkah penggunaan media videoyang dikombinasikan dengan model pembelajaran investigasi kelompok sudah baik. Hal ini diperkuat dengan hasil observasi bahwa guru dalam langkah pelaksanaan tugas telah memberikan bimbingan dan dorongan agar siswa dalam mengerjakan tugas harus dikerjakan sendiri tanpa menyuruh orang lain dan setelah itu mencatat hasilhasil yang diperoleh.Aktivitas siswa pada aspek afektif atau keaktifan siklus I yaitu sebesar $60 \%$, meningkat $16 \%$ pada siklus II yaitu sebesar $76 \%$, dan meningkat $12 \%$ pada siklus III yaitu sebesar $88 \%$. Sedangkan pada aspek psikomotorik atau ketrampilan hasilnya siklus I sebesar 56\%, meningkat sebesar $20 \%$ pada siklus II yaitu $76 \%$ dan meningkat lagi sebesar $16 \%$ pada siklus III yaitu $92 \%$.

2. Hasil belajar siswa meningkat. Hal ini ditunjukkan dengan peningkatan persentase hasil belajar siswa dari aspek kognitif. Pada aspek kognitif, mulai dari siklus I yaitu 19\%, meningkat $48 \%$ pada siklus II yaitu sebesar $67 \%$, dan mengalami peningkatan lagi sebesar $30 \%$ pada siklus III yaitu $97 \%$.

\section{DAFTAR PUSTAKA}

Anitah, S. (2012). Media Pembelajaran . Surakarta: Mata Padi Presindo.

Arifin, Z. (2014). Evaluasi Pembelajaran . Bandung: Remaja Rosdakarya.

Arsyad, A. (2013). Media Pembelajaran. Jakarta : Rajawali Press.

Dwi Rahmawati, E. (2012). Penerapan Model Pembelajaran Kooperatif Tipe Group Nvestigation (Gi) Untuk Meningkatkan Keaktifan Belajar Dan Hasil Belajar Mata Pelajaran Sosiologi Pada Siswa Kelas X 3 Sma Negeri Colomadu Tahun Pelajaran 2011/2012. Jurnal Sosialita, 1-6. 
Gunawan, I.(2016). Taksonomi Bloom - Revisi Ranah Kognitif:Kerangka Landasan Untuk Pembelajaran,Pengajaran, Dan Penilaian. Unipma, 98117.

Haryoko, S. (2009). Efektivitas Pemanfaatan Media Audio-Visual Sebagai Optimalisasi Model Pembelajaran.Edukasi@Elektro , 1-10.

Lingin. (2012). Pengembangan Media Pembelajaran Interaktif Pada Mata Pelajaran Geografi. Unimed, 15-21.

Miskowati, M. (2012). Pembangunan Media Pembelajaran Geografi Untuk Siswa Kelas VII Sekolah Menengah Pertama Negeri 1 Karangpandan Berbasis Multimedia Interaktif . Journal Speed - Sentra Penelitian Engineering dan Edukasi, 35-39.

Riyana, C. (2007). Pedoman Pengembangan Media Video . Jakarta : P3AI UPI.

Sadiman, A. (2012). Media Pendidikan. Jakarta: Raja Grafindo Persada.

Sulasti, N. W. (2013). Penerapan Model Pembelajaran Kooperatif Tipe Group Investigation (GI) Untuk Meningkatkan Aktivitas dan Hasil Belajar Siswa Dalam Pelajaran PKn Di Kelas XI IPA 1 SMA Negeri 1 Sawan Tahun Ajaran 2012/2013. Undiksha, 1-12. 